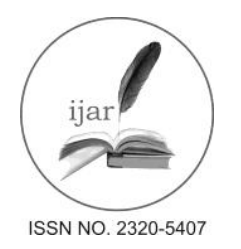

Journal homepage: http://www.journalijar.com

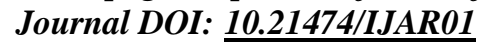

INTERNATIONAL JOURNAL

OF ADVANCED RESEARCH

RESEARCH ARTICLE

\title{
PRECURSORS AND OUTCOMES OF ORGANIZATIONAL CUTLTRE IN HIGHER EDUCATION: A THEORETICAL PERSPECTIVE.
}

1. Research Scholar, IFTM University, School of Business Management, Lodhipur Rajput, Delhi Road NH-24, Moradabad, Uttar Pradesh 244102.

2. Assistant Professor, Amity University, Sector 125, Noida, Uttar Pradesh 201313. India.

\section{Manuscript Info}

Manuscript History:

Received: 28 April 2016

Final Accepted: 11 May 2016

Published Online: June 2016

Key words:

Organizational culture (OC), Higher

Education (HE), Conceptual

Framework Integration,

Differentiation, Subculture.

*Corresponding Author

Saba Hussain.

\section{Abstract}

The purpose of this study is to explore the concept of culture in higher educational context. Research aimed to identify and discuss the properties of academic culture and examine how cultural concepts can be use to describes practices in private colleges and universities of Delhi/NCR. We came up with the factors contribute to shape culture, and its results into a framework, to encompass manifestations of organizational culture in relation to academic excellence. By canvassing the literature, tried to develop a picture of academic culture and its contribution to academic practices and excellence.

Copy Right, IJAR, 2016,. All rights reserved.

\section{Introduction:-}

Numerous researchers have studied the culture concept in HE specially its relation to the ways of perceiving governance of colleges and university, performance driver, student and faculty culture and information and knowledge management etc.

Culture impacts most aspects of organizational life, such as how decisions are made, who takes the ownership, how people are rewarded, how people are promoted, how people are treated, how they response to the environment, and so on. Culture influences people's belief, attitude and behavior at work.

According to Needle (2004[1])...

"Organizational culture represents the collective values, beliefs and principles of organizational members and is a product of such factors as history, product, market, technology, and strategy, type of employees, management style, and national culture".

\section{Culture in Higher Educational Context:-}

Research on OC in academics can be traced back to the 1930s (Trice \& Beyer 1993[2]). This concept began to receive serious attention since the 1980s with the work of Peters and waterman (1982a) and Ouchi (1981) [3, 4]. Initially the research in HE resulted in ethnologic studies of universities and colleges (Clark 1960a; Trow 1960; Barton 1961[5, 6, 7]). Researchers were interested to investigate the culture influence on students as indicated by pace (1962[8]). Instruments were developed to analyze culture like College Characteristics Index (CCI) by Peace and Stern (1958[9]). 
In 1960s and 1970s area of culture studies in HE was limited to its impact on student. A shift was noticed. During 1980s researchers struggled to define OC and climate and how organizational culture improves institutional effectiveness.

Burton Clark's (1972a [10]) work on organizational saga is even the only literature stemming from the field of higher educational literature. He introduces higher education culture as study of environment, mission, socialization, information, strategy and leadership. Other authors who have attempted to conceptualize OC in HE, Dill (1982[11]), Masland (1985[12]) and Bergquist (1992[13]). The concept of OC has been recognized as a critical element in the study of HE (Peterson \& Spencer 1993[14], Hardy 1990[15]) argued that 'the research in HE is far behind the management literature in terms of its understanding of culture'. One of the landmarks in the studies of HE institutions as cultural entities is the work of Riesman and Jencks (1962[16]). For them, college appeared not only as an organization, but as a subculture "with its own idiosyncratic customs and concerns". They also suggested that there is a need for anthropological field work to investigate not only students, but also "the student culture", "the faculty culture", and other subgroups that make up the college.

The mentioned studies provided the theoretical evidence on the process of culture formation in colleges and universities. After so many years of emerging culture concept in academic or HE, comparatively a small numbers of studies have tried to look in to the concept of culture-academic practice in general. In particular, there are few researches identified the influence of psychological empowerment and commitment as individual characteristics, and the influence of $\mathrm{OC}$ as organizational factors on it. We found this to be a serious research gap. As the depth and speed in change of today's business environment due to globalization, technological innovation, and the knowledgebased economy, jobs have become more complex, challenging. Thus, it is culture that may have an influence on employee efficiency, performance, psychological empowerment and commitment to organizations. It is also possible that the uniqueness of the culture has an impact on the market or economical performance. This study intends to fill this research gap, focusing on the role of culture in HE.

\section{Literature Review:-}

When we talk about the cultural perspectives in general, we focus on various cultural properties, such as language, stories, belief systems, values, rituals, ceremonies, or a set of basic assumptions. George D. Kuh, Elizabeth J. Whitt (1988 [17]), Identified the ways cultural perspectives have been used to describe college life, examines intellectual foundations of culture, institutional subcultures and implications for practice.

Culture, therefore, is a result of group's social learning influenced by its history. It is an outcome of the group learning experiences. Once a group acquires a history, it also acquires a culture (Schein, 1985, 1987[18, 19]). Becher (1984[20]) define culture....

"The traditional and social heritage of a people; their customs and practices; their transmitted knowledge, beliefs, law, and morals; their linguistic and symbolic forms of communication, and the meanings they share". Uttal (1983[21]) defined culture as: "...

A system of shared values (what is important) and beliefs (how things work) that interact with a company's people, organizational structure, and control systems to produce behavioral norms".

External environment is an active environment, changes, events and trends in the external environment effect internal environment too. When one confronts the external environment with the (internal) cultural factors one would be able to portray how $\mathrm{HE}$ can fulfill needs and ambitions as defined in the external environment (S.Beltman $2009[22])$.

The ecological -adaptation school of thought depict culture as a system of socially transmitted behavior that serves to link individual, group or communities to their ecological system. Environment has an active and significant role in challenging evolution of culture. Clark (2004[23]) asked two fundamental questions: How are entrepreneurial universities formed? How do they sustain themselves? In discussing these questions, Clark emphasized that such universities are constructed through a combination of structural and cultural factors providing these universities with a distinctive identity that also enables them to maintain a steady and adequate state of change in a shifting environment. 
In HE, culture is formed through many complex influences both in the organization and as the result of the environment. Within the organization, culture is the result of an organization's unique history (Clark 1972 [24]), its leadership (Schein, 1983, 1984 [25, 26]), and critical events (Pettigrew, 1979[27]).

The country's environment form a ground within which an organization operates. The extent to which government and its bureaucracy supports and contributes resources to the institution, institution's involvement with legal context as institutions require specific legal status to operate, external funding etc, whether the conditions are friendly or hostile affects institution's functioning.

Schein (2004a [28]) believes that.......

Culture and leadership are two sides of the same coin. When organizations start there is always a leader who has a preferred way of doing things, and those preferences by definition are going to be imposed on the group members. The leader's values and preferences are the first ways that a group or organization does things and if that works it becomes eventually the culture of that group. So in a very real sense, founders and leaders create culture."

Richard Barrett (2006[29]) interpreted that...

"The culture of an organization is either a reflection of the personal consciousness of the leadership group (conscious or subconscious) or is inherited from previous leadership groups".

Culture is made up of organizational history, formal structure, strategies, policies, management process, vision, goals, objectives, authority and power structure.

The interpretation taken by the organizational literature appears to be a response to the sociological, psychological and anthropological perspectives. Such a perspective promotes a definition of culture as, "the deep structure of organizations, which is rooted in the values, beliefs, and assumptions, held by organizational members" (Denison, 1996[30]).

The academic culture is a great tapestry, where the beliefs and practices of trustees, senior administrators, faculty members, campus community members, Students, competitors, and society shape the academic culture. A strong and deep understanding of tradition and history is necessary for an academic social system to thrive; Vision, goals, hierarchies, structure and policies can comprise a shared mental model that allows all faculty and staff to give meaning to external and internal occurrences.

Tiemey (1988[31]) said that.....

"To study OC in HE, that is environment, mission, socialization, information, strategy and leadership, are no operationalizations of cultural concepts, but are claimed to be 'key dimensions of culture' themselves".

Social psychology aspects comprise of scientific study of how people think about, influence, and relate to other, sociology and psychology of institutional life must attempt to understand the dynamics internal to the institution as well as external factors and forces that influence the behavior of faculty, students, and administrators. Social psychology and communications, all contribute to shape and understand institutional culture.

Social cognition is a growing area of social psychology that studies how people perceive, think about each other. People think about other people or object differently. The study of how people form beliefs about each other while interacting is known as interpersonal perception.

The term psychosocial refers to the close connection between psychosocial aspects of our experiences (e.g. our thoughts, emotions, and behavior) and our wider social experience (e.g. our relationships, tradition and culture). Learners and teachers are psychologically affected by the surrounding social conditions that may disrupt or enhance the quality and effectiveness of learning.

Ravasi and Schultz (2006[32]) wrote that....

"Organizational culture is a set of shared mental assumptions that guide what happens in organizations by defining appropriate behavior for various situations. It is also the pattern of such collective behaviors and assumptions that are taught to new organizational members as a way of perceiving and, even, thinking and feeling. Thus, 
OC affects the way people and groups interact with each other, with clients, and with stakeholders. In addition, OC may affect how much employees identify with an organization".

Artifactual manifestations of culture, such as architecture, customs, ceremonies, and rituals reflect culture of the organization.

The physical environment reflects distinctive values and aspirations of those who live and work in a college (Sturner 1972[33]). Sometimes additions to the physical structure have been made in an effort to change an institution's external image. Culture is carried and reflected by the academic program, social environment, and artifacts such as language, ceremonials, stories, and heroes. All such artifacts have an impact to form employee's perception towards the organization. Sociology and the sociocultural tradition in anthropology address the rational aspects of a college or university and underscore the importance of formal organizational structures and subcultures in transmitting values and beliefs and influencing the behavior of faculty and students.

Institutional culture is both a process and a product. As a process, culture shapes by, the ongoing interactions of people on and off campus. As a product, culture reflects interactions among history, traditions, organizational structures, and the behavior of current students, faculty, and staff. Artifacts are observable manifestations of culture, such as the institutional mission statement, architecture, academic program, language, myths, stories, symbols, rites and rituals, and ceremonials. Culture revealed core values, beliefs and assumptions shared by institutional leaders, faculty, students, support staff and other members, such as alumni and parents.

Culture develops from interplay between the external environment and internal institutional features, such as an institution's historical roots, including religious convictions of founders, philosophy, vision statement, power structure etc, and external influences, particularly the society, legal structure, global influences etc. The academic program; faculty, administrators; and other stakeholders determined cultural artifacts, such as architecture, customs, stories, language, and so on; distinctive themes that reflect core values and beliefs and make up the institution's ethos.

Key elements that contribute to a college or university's culture include mission and goals of the institution, governance structure and leadership style of administrators, curricular structure and academic standards, student and faculty characteristics, student-faculty relations, size and location, and physical environment. The characteristics of each element and their interactions with each other create a unique culture for each college and university (Peterson, Cameron, Jones et. al. 1986[34]).

Organizational culture emerges as a major research area in HE. Higher educational institutions in many ways operate similar to other organizations and also function in environments that are characterized by government, market forces, globalization, internationalization, paradigm shift from teaching to learning, new technologies, global competition (Levine, 2000; Middlehurst \&Woodfield, 2004 [35, 36]).

Before we developed a conceptual model for academic, it is necessary to examine how cultural has been applied to $\mathrm{HE}$ in general. Most of the literature on OC arose out of the corporate sector; eventually academic culture is an almost neglected concept in Indian context in both aspect literature and practice. Universities and colleges do not operate in a wholly profit-cantered environment. Out of this environmental approach institutional cultures evolves a uniquely structured setup with its multifaceted goals, multitude of offerings it's require a malleable framework for assessment.

Culture in HE is considered as a collective, mutually shaping patterns of norms, values, practices, beliefs, and assumptions that guide the behavior of individuals and groups and provide a frame of reference within which to interpret the meaning of events and actions on and off campus.

A number of scholars have adopted more rational approaches and tried to explain the functioning of universities and colleges interpreting the structure and nature through analyzing the impact of disciplines on attitudes, values and behaviors of academics employed by these institutions, Becher (1981 [37]). 
Zsóka(2007[38]) define.....

"Organizational culture is the system of assumptions, values, convictions and beliefs accepted and commonly interpreted by the members of the organization. It reflects both the real and the declared values of the company and its members".

Bartell (2003[39]) culture at university level.....

"Is described as a values, believes and common objectives between the faculty members, managers, student and the university employees. These values and believes affect the process of the decision making at the universities to a large extent and shape personal and organizational behavior".

Values, organizational norms, guidelines, or expectations that prescribe appropriate kinds of behavior by employees in particular situations and control the behavior of organizational members towards one another (Black \& Richard, 2003[39]).

Schein (2004b [40]) defines organizational culture....

"As a pattern of shared basic assumptions that was learned by a group as it solved its problems of external adaptation and internal integration, which has worked well enough to be considered valid and, therefore, to be taught to new members as the correct way they perceive, think, and feel in relation

to those problems".

Organizational culture is generally considered to be, at its deepest level, a cognitive phenomenon, "the collective programming of the mind" (Hofstede, 2011 [41]). However, though OC may reside in the collective minds of organizational members, it is manifested in tangible ways, such as behaviors, throughout the organization (Detert, Schroeder \& Mauriel, 2000[42]).

Thus, OC is viewed as the pattern of basic assumptions, beliefs and meaning that guides organizational behavior (Martin 2002[43]), and he identified three different perspectives on OC: integration, differentiation, and fragmentation, but Schein (2004c [44]) integrative, No study portrays each perspective in its ideal type, but each study stresses different phenomenon. Therefore, to categorize a research study, one must look at what phenomena are foreground and background. In differentiation studies, multiple subcultures are described and differences between them are stressed, while in integration studies, organization-wide consensus is stressed and subcultural differences are of secondary importance (J.C. Smart 2010 [45]).

OC comprises of values, assumptions, stories, collective memories, Culture itself manifests several characteristics and affects people's understanding about it. It's socially constructed, its core lies in social, historical interaction within society or institution among people and the way they perceive and interpret the world around. Culture develops in long run as a result of the result of social interaction, tradition, history, leadership and several other internal and external forces. Culture is shaped by subcultures, including at the broadest level the subcultures of faculty and administration (Van Maanen \& Barley, 1984[46]).

The integration perspective assumes consistency, organization-wide consensus, and clarity on the other hand differentiation perspective assumes that culture is manifested by differences among subunits, and that consensus only occurs in subcultures. This perspective can be clearly seen in Clark's book Academic Life: Small Worlds, Different Worlds (1987[47]). Within the integration perspective, culture is the shared understandings in a given organization and multiple cultures will probably share some elements of the dominant culture. There is a consistency across cultural manifestations (Meyerson and Martin, 1987[48]).

Knowing differentiation and integration aspects can help to understand institutional behavior.

\section{Culture and its Impact:-}

The concept of culture has recently been widely used in the context of organizations. Numerous researches have been done to analyze culture dimensions and its impact on various aspect of academic life. Cameron and Quinn (2006[49]) stated that most organizational scholars and observers have recognized the powerful effect of culture on the performance and long-term effectiveness. 
Although there is no consensus as to what actually culture is and how pervasive it in academic, there is a general agreement that culture is a major force affecting employee behavior, motivation, commitment and organizational effectiveness, it may be one of the decisive influence for the survival or fall of the organization (Marcoulides \& Heck, 1993; Schein, 1985a, 1990, [50, 51, 52]).

Numerous factors influence the ultimate performance of any education institution. One among these factors is the prevailing culture of an institution. Schein (2002[53]) has cautioned that researchers have underestimated the extent to which culture contributes to the performance of an organization, as either an asset or a liability and as the explanatory construct underlying numerous organizational phenomena.

Raduan et. al. (2008[54]) observes, A high degree of organization performance is related to an organization, which has a strong culture with well integrated and effective set of values, beliefs and behaviors. Moreover studies done by Denison and Mishra (1995[55]), Kotter and Heskett (1992[56]), contributed significantly to the field of culture and organization performance.

There is no doubt that the type of culture prevailing in an institution has a great bearing on its performance, $\mathrm{M}$. James (2002[57]) addressed a positive relationship between culture, employee satisfaction, customer satisfaction, and organizational performance. It has been widely argued that culture has a considerable influence on organizational behavior, particularly in areas such as performance and commitment (van Vianen, 2000[58]). Ramseden, (2005[59]) stated that culture affects universities performance and effectiveness.

Marta-Christina et. al. (2012[60]) considered, trust, cultural identity and cooperation as 'soft concepts', intellectual capital as a source of "long-run sustainability", and also a competitive advantage for the knowledge-based organizations. Ellinger et al. (2002[61]); Gilley and Maycunich (2000[62]); presented culture in academic as a source of organizational competitive advantage.

Shapiro (1988[63]) focuses on customer orientation as culture, In other words, customer focus is a sort of OC that leads to the creation of customers' best value in the most efficient and effective manner.

Cheng YC, Tam WM (1997[64]), Today's challenges of quality and customer focus improvement and systems development in $\mathrm{HE}$ are important and inevitable.

Lewis and Smith (1994 [65]) observed that "every college and university has a mission but very few fully identify who they serve". Rinehart, 1993[66], Employers expect colleges and universities to produce well-qualified and trained graduates who could work efficiently and effectively in the jobs for which they have been hired. They need workers who have communication and problem-solving skills and are willing and able to learn their specific jobs quickly and effectively. There are some highly competitive challenges among educational institutes, including accountability to social needs, increasing costs of education, diversity in educational methods and consequent increasing competition, and the need for adaptation of new information and knowledge to focus on students as the main customers.

Today's crisis in the quality of learning in HE is fundamentally a problem in culture. The exiting culture in college or university -- the shared norms, values, standards, expectations and priorities -- of teaching and learning on most campuses is not powerful enough to support true higher learning. As a result, students do not experience the kind of integrated, holistic, values that truly transformative higher learning.

The concept of empowerment was first introduced in 1980s (Blanchard et al., 1996; Whetten and Cameron, 1998[67, 68]). However, in 1990s substantial interest has been generated towards this concept among researchers, university lectures, and management specialists (Conger and Kannungo, (1988[69]); Bowen and Lawler, (1995[70]); Thomas and Velthouse, 1990[71]; Spreitzer, 1995[72]).

Empowerment develops professional growth in abilities and skills, self-efficacy and performance and decreases turnover of employers (Biron \& Bamberger, 2010; Logan \& Ganster, 2007; Yang \& Choi, 2009[73, 74, 75]). 
Employee empowerment is one of the most successful ways to improve employee motivation, organizational commitment and job satisfaction, and a great deal of effort has been expended to explore empowerment in organizations (Henkin \& Marchiori, 2003; Laschinger, Finegan, \& Wilk, 2009; Manojlovich \& Laschinger, 2002; Wang \& Lee, 2009[76, 77, 78]).Empowered teachers encourage colleagues to improve student achievement and teacher's leadership is become a mean of coping with change more meaningfully and successfully (Anderson, 2004[79]). Teacher empowerment creates a positive learning environment which encourages risk-taking, personal commitment and involvement, decision-making and professional growth will enhance teachers' sense of selfefficacy (Martin, Crossland, \& Johnson, 2001[80], O'Connor \& Korr, 1996; Ashton, et al., 1983 [81]).

According to Hoppock (1935[82]) job satisfaction is "any combination of psychological, physiological, and environmental circumstances that causes a person to say, I am satisfied with my job.

A large number of researchers, link job satisfaction with organizational culture; it increases the satisfaction level of the employees and decreases the turnover ratios from the organization. (Taber 1975 [83]), (Jiang and Klen 2000[84]), (Rad 2006[85]), (Arnold 2006[86]), and (Chang and Lee 2007[87]) etc.

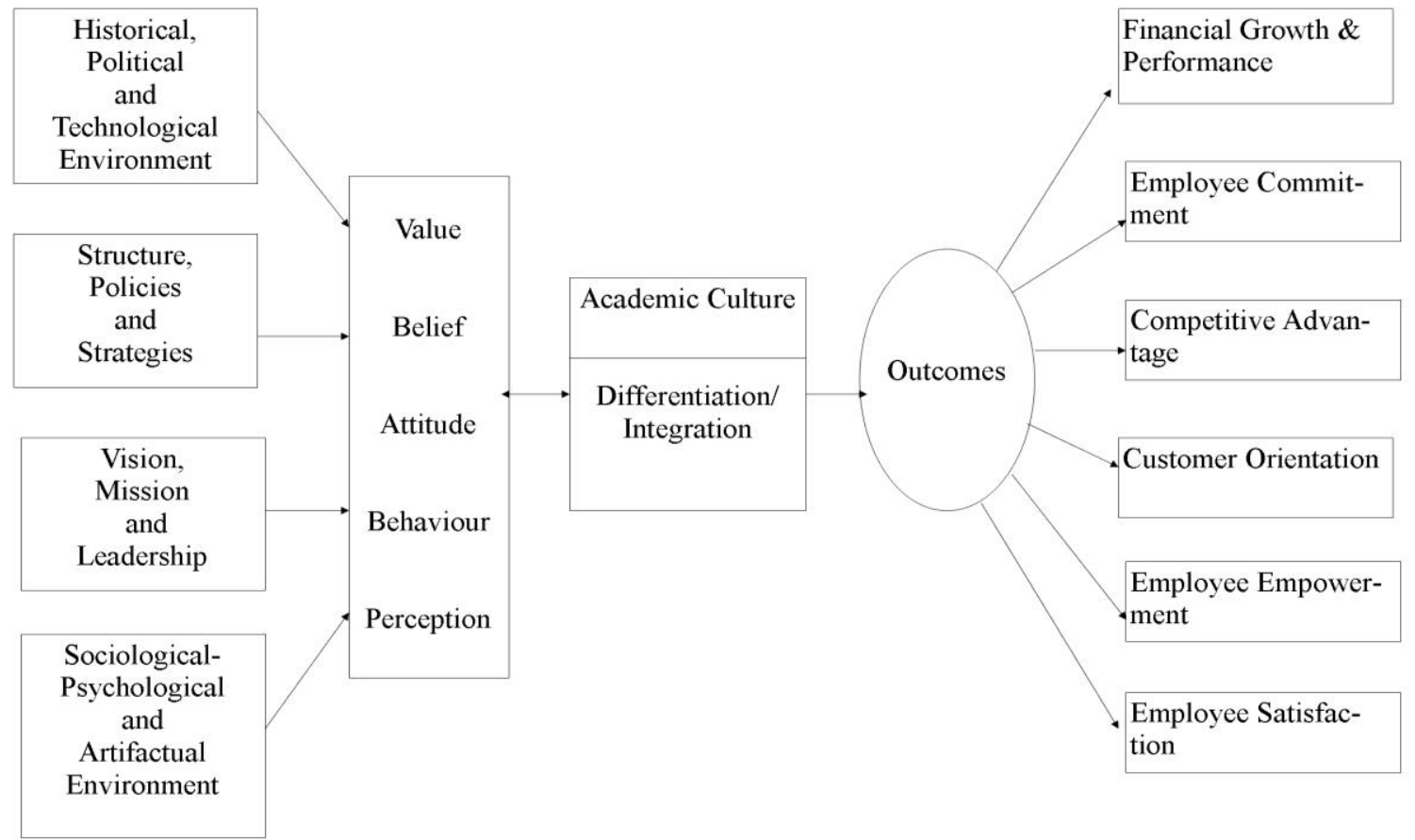

Figure 1:- Organizational Culture: Conceptual Framework.

The above insights of literature make us to conclude that organization culture influence organization functioning in many ways. The literature also shows a lack of study about the relationship between organizational culture and psychological empowerment and commitment among academicians in universities.

\section{Discussion:-}

Traditionally various methods and approaches have been applied to study culture aspect. Socioculture, ecological, structural, symbolic and cognitive approach provide a deeper insight of culture emergence and its association with value creation, as shown in figure 1. Social science research is not well suited for identifying properties of institutional culture. Cultural perspectives help in examining and understanding events in an institution and the behavior of faculty, students, and administrators. History, Political \& legal environment, Goals, internal policies and procedures, strategies, routine practices and leadership activities I more complex meaning in if viewed as cultural phenomena.

Organization concept is being used in a wide field and it is getting great importance day by day. This is why most of researchers study this concept. 
The literature highlights a number of tools and methods useful in studying, analyzing and assessing organizational culture. Among them we can mention: literature review, observation, interview, questionnaire, additional investigations. The instruments listed can be classified into two broad categories: qualitative and quantitative methods.

A first qualitative method used in analyzing organizational culture is also the literature review. It is based on deciphering the elements of the company by researching certain historical, financial reports, procedures, various press releases, annual report, organizational diagrams and charts etc.

The other methods include observation, structured and unstructured interview, questionnaire survey etc. Various instruments have been used for exploring organizational culture:

Assessing Learning Culture Scale, Competing Values Framework, Organizational Culture Assessment Instrument (OCAI) (Cameron and Quinn). Corporate Culture Questionnaire, Culture Gap Survey, Culture Survey, The Cultural Audit, Cultural Assessment Survey, Denison Organizational Culture Survey, Hofstede's Culture Measure, Hofstede's Culture Measure of Organizational Culture, Organizational Culture Assessment Instrument, Organizational Culture Inventory. Competing Values Framework and Organizational Culture Assessment Instrument has been extensively used by the researches to explore academic culture.

\section{Limitations and Recommendations for Future Research:-}

Despite the wealth of research linking organizational culture with job satisfaction, commitment, performance and effectiveness, there is an absence of research that examined effectiveness, commitment and empowerment at the subunit level. In addition, literature also lacking pertaining to historical, legal political and environmental effects on institute/university's functioning mostly researcher focused on dimensional approach to analyze culture. To gain a better understanding of how culture work and influence various units, research needs to be done to explore institution's culture at various level and it influence on various subgroups functioning.

Additional studies may also be done which examine how gender affects leadership behavior and its impact on organizational culture, performance and decision-making? It's Dominating culture or subculture that has greater impact on employee commitment? The impact of university or institution's philosophy, values, on student's performance. Explore employee psychological empowerment in various academic unite. There's an absence of literature addressing organizational culture and effectiveness for minority institutions, specifically at the sub-unit level.

Ultimately, the report demonstrates the alternative ways of thinking about education in order to shift thinking away from education as a place of getting degree, toward the social purposes and importance of higher education in reforming the educational system. Institutions can be given new frames and reformers can activate a different set of cultural models, the public will be better positioned to think about and understand the broader societal benefits of education and the need for educational reform.

\section{References:-}

1. Anderson, K. (2004): The nature of teacher leadership in schools as reciprocal influence between teacher leaders and principals. School Effectiveness and School Improvement, [79], 97-113.

2. Arnold, T. and Spell, S. C. (2006): The Relationship between Justice and Benefits Satisfaction. Journal of Business and Psychology, [86], 599-620.

3. Azaola, Marta Cristina .(2012): Revisiting Bourdieu: Alternative Educational Systems in the Light of the Theory of Social and Cultural Reproduction. International Studies in Sociology of Education, [60], 81-95.

4. Bartell, M. (2003): Internationalization of Universities: A University Culture-Based Framework. Higher Education, [39], 43-70.

5. Barton, A.H. (1961): Organizational Measurement and its Bearings on the Study of College Environments. Research on Monograph". New York: College Entrance Examination Board, [7].

6. Becher, T. (0981): Towards a Definition of Disciplinary Culture. Studies in Higher Education, [37], $109-119$.

7. Becher, T. (1984): The Cultural View". In B. R. Clark (Eds) Perspectives on Higher Education. Berkeley: University of California Press, [20], 163-198.

8. Bergquist, W.H. (1992): The Four Cultures of the Academy: Insights and Strategies for Improving Leadership in Collegiate Organization. San Francisco: Jossey, [13]. 
9. Biron and Peter Bamberger. (2010): The Impact of Structural Empowerment on Individual Well-Being and Performance: Taking Agent Preferences, Self-Efficacy and Operational Constraints into Account. Sage Publication, [73], 164-186.

10. Blanchard K, Carlos J, Randolf A. (1996): Empowerment Takes More Than a Minute. San Francisco, CA: Berrett - Koehler Publishers, [67].

11. Bowen DE, Lawler EE (1992): The Empowerment of Service Workers: What, Why, How, and When. Sloan Manage. Rev, [70].

12. Cameron, K. S., \& Quinn, R. E. (2006): Diagnosing and Changing Organizational Culture. (Rev. Ed.). New York: Jossey-Bass, [49], 22-250

13. Chang, S. and Lee, M. S. (2007): A study on the Relationship Among Leadership, Organizational Culture, The Operation of Learning Organization and Employees job satisfaction. Learning Organization, [87], $155-185$.

14. Cheng YC, Tam WM. (1997): Multimodels of Quality in Education. QualAssur Education, [64], 22-31.

15. Clark, B. R. (1987): The Academic Life: Small Worlds, Different Worlds. Princeton NJ: Carnegie Foundation for the Advancement of Teaching, [47], 165-375.

16. Clark, B.IL. (1972a): The Organizational Saga in Higher Education. Administrative Science Quarterly, [10]).

17. Clark, B.R. (1960a): The Open Door College. New York: McGraw-Hill, [5].

18. Clark, B.R. (1972): The Organizational Saga in Higher Education. Administrative Science Quarterly, [24], 178184.

19. Clark, B.R. (2004): Delineating the Character of the Entrepreneurial University. Higher Education Policy, [23], 355-370.

20. Conger JA, Kanungo RN. (1988): The empowerment process: integrating theory and practice. Acad. Manage. Review, [69].

21. Denison D R. (1996): What is the Difference between Organizational Culture and Organizational Climate? A Native's Point of View on a Decade of Paradigm Wars. Academy of Management Review, [30], 619-654.

22. Denison, D. and Mishra, A. (1995): Toward a theory of organizational culture and effectiveness. Organizational Science, [55], 204-223.

23. Detert, J., Schroeder, R., \& Mauriel, J. (2000): A Framework for Linking culture and Improvement Initiatives in Organizations. The Academy of Management Review, [42], 850-863.

24. Dill, D.D. (1982): The management of academic culture: notes on the management of meaning and social integration. Higher Education, [11].

25. Ellinger, A.D., A.E. Ellinger, B. Yang, and S.W. Howton. (2002): The relationship between the learning organization concept and firms' financial performance: An empirical assessment. Human Resource Development Quarterly, [61], 5-21.

26. George D. Kuh, Elizabeth J. Whitt. (1988): The Invisible Tapestry: Culture in American Colleges and Universities. Wiley, [17], 4-160.

27. Gilley, J.W., and A. Maycunich. (2000): Organizational learning, performance and change: An introduction to strategic human resource development. Cambridge, MA: Perseus Publishing, [62], 64-440.

28. Hardy, C. (1990): Putting power into university governance. In J.C. Smart (Eds). "Higher Education: Handbook of Theory and Research". New York: Agathon Press, [15], 393.

29. Henkin, A. B., \& Marchiori, D. M. (2003): Empowerment and organizational commitment of chiropractic faculty. Journal of Manipulative and Physiological Therapeutics, [76], 275.

30. Hofstede, G. (2011): Dimensionalizing Cultures: The Hofstede Model in Context. Online Readings in Psychology and Culture, [41], 3.

31. Hoppock, R. (1935): Job Satisfaction, Harper and Brothers. New York, [82], 47.

32. J.C. Smart (Eds.) (2010): Higher Education: Handbook of Theory and Research. Springer, [45], 384.

33. Jencks, C. And Riesman D. (1962): The viability of American College. In N. Stanford (Ed.). "The American College, Psychological and Social Interpretation of the Higher Learning". New York Wiley, [16], $74-104$.

34. Jiang. J .J and Klein, G. (2000): Supervisor Support and Career Anchor Impact on Career Satisfaction of the Entry Level Information System. Journal of Management Information System, [84], 219-240.

35. Kotter, J.P and Heskett,J.L (1992): Corporate Culture and Performance. New York: Free Press, [56], 10-179.

36. Laschinger, H. K. S., Finegan, J., \& Wilk, P. (2009). Context Matters the Impact of Unit Leadership and Empowerment on Nurses' Organizational Commitment. The journal of Nursing Administration, [77], $260-272$.

37. Levine, A.E. (2000): The Future of Colleges: 9 Inevitable Changes. Retrieved from Chronicle of Higher Education. http://chronicle.com/article/The-Future-of-Colleges, [35].

38. Lewis, R.G., Smith, D.H. (1994): Total Quality in Higher Education. Delray Beach, FL: St. Lucie Press [65], 91. 
39. Logan, M. S. \& Ganster, D.C. (2007): The Effects of Empowerment on Attitudes and Performance: The Role of Social Support and Empowerment Beliefs. Journal of Management Studies, [74], 1523-1548.

40. Marcoulides, G. A., \& Heck, R. H. (1993): Organizational culture and performance: Proposing and testing a model. Organization Science, [50], 209-229.

41. Martin, B. N., Crossland, B., \& Johnson, J.A. (2001, November): Is There a Connection: Teacher Empowerment, Teachers' Sense of Responsibility, and Student Success. Paper presented at the Mid-South Educational Research Association Annual Meeting, Little Rock, AK, [80], 1-23.

42. Martin, J. (2002 ): Organizational Culture: Mapping the Terrain. London: Sage, [43], 47-295.

43. Masland, AT. (1985): Organizational Culture in the Study of Higher Education. The Review of Higher Education, [12].

44. Meyerson, D., \& Martin, J. (1987): Cultural change: An Integration of Three Different Views. Journal of Management Studies, [48], 623-647.

45. Middlehurst, R. and Woodfield, S. (2004): The Role of Transnational, Private, and For-Profit Provision in Meeting Global Demand for Tertiary Education: Mapping, Regulation and Impact. Case Study Malaysia. Summary Report. Report Commissioned by the Commonwealth of Learning and UNESCO, [36].

46. Needle, David. (2004): Business in Context: An Introduction to Business and Its Environment. Cengage Learning EMEA ISBN 978- 1861529923, [1].

47. Ng'ang'a, M James Nyongesa, Wj. (2012): The Impact of Organizational Culture on Performance of Educational Institutions. International Journal of Business and Social Science, [57], 211-217.

48. O'Connor, R. \& Korr, W. S. (1996): A Model for School Social Work Facilitation of Teacher Self-Efficacy and Empowerment. Social Work in Education, [81], 45-52.

49. Ouchi,W. G. (1981): Theory Z. Reading. MA: Addison-Wesley, [4].

50. Pace, C. R., \& Stern, G. G. (1958): An approach to the Measurement of Psychological Characteristics of College Environments. Journal of Educational Psychology, [9], 269-277.

51. Pace, C.IL. (1962): Methods of describing college culture. Teachers College Record, [8], 267-277.

52. Peters, T.J. \& Waterman, R.H. (1982a): In Search of Excellence. Harper \& Row, New York, [3].

53. Peterson, M. W., Cameron, K. S., Jones, P., Mets, L. A., \& Ettington, D. (1986): The organizational context for teaching and learning: A review of the research literature. Ann Arbor, MI: National Center for Research to Improve Postsecondary Teaching and Learning, University of Michigan, [34].

54. Peterson, M.W. and Spencer, M.G. (1993): Qualitative and Quantitative Approaches to Academic Culture: do they tell us the same thing?" In J.C. Smart (Ed), Higher Education: Handbook of Theory and Research. New York: Agathon Press, [14], 344-388.

55. Pettigrew, A. M. (1979): On studying organizational culture. Administrative Science Quarterly, [27], $13-15$.

56. Rad. A., Mohammad. M., Mohammadian, Y. and Hossein. (2006): A study on the relationship between managers leadership style and employees job satisfaction. Emerald Group Publishing Limited, [85], 11-24.

57. Raduan, C. R., Kumar, N., Haslinda, A. \& Ling, G. Y. (2008): Organizational Culture as a Root of Performance Improvement: Research and Recommendations. Contemporary Management Research, [54], 43-56.

58. Ramsden, I. (2005): Towards cultural safety.In D. Wepa (Ed.), Cultural Safety in Aotearoa New Zealand. Auckland: Pearson Education New Zealand, [59], 2-20.

59. Ravasi, D., Schultz, M. (2006): Responding to organizational identity threats: exploring the role of organizational culture. Academy of Management Journal, [32], 433-458.

60. Richard Barrett. (2006 ): Building a Values Driven Organization: A Whole System Approach to Cultural Transformation. Butterworth-Heinemann, [29], 80.

61. Rinehart. (1993): Quality Education.Applying the philosophy of Dr. W. Edward, to transform the educational system. American society for quality control, [66].

62. Schein. (2002): Models and Tools for Stability and Change in Human Systems. The Society for Organizational Learning and the Massachusetts Institute of Technology, [53], 34-46.

63. Schein, E. H. (1983): The role of the founder in creating organizational culture. Organizational Dynamics, [25], 13-28.

64. Schein, E. H. (1984): Coming to a new awareness of organizational culture. Sloan Management Review, [26], $3-16$.

65. Schein, E. H. (1985a): Organizational culture and leadership. San Francisco: Jossey-Bass, [51], 365.

66. Schein, E. H. (1987): Corporate culture. Chemtech, [19], 80-84.

67. Schein, E. H. (1990): Organizational Culture. American Psychologist, [52], 109-119.

68. Schein, E. H. (2004c): Organizational culture and leadership (4rd ed.). San Francisco: Jossey- Bass, [44], 17295. 
69. Schein, E.H. (1985a): How Culture Forms, Develops and Changes". San Francisco, Calif.: Jossey - Bass, [18].

70. Schein, E.H. (2004a): Organizational Culture and Leadership. Jossey-Bass, San Francisco, [28], 3-10.

71. Schein, E.H. (2004b): Organizational Culture and Leadership. Jossey-Bass, San Francisco, [40], 17.

72. Schelte Beltman. (2009): Cultural Capital as a Driver for Performance in Higher Education. Proceedings of the European Conference on Intellectual Capital, [22], 83.

73. Shapiro B. (1988): What the hell is market oriented? Harvard Business Review, [63], 1-11.

74. Spreitzer GM. (1995): Psychological empowerment in the workplace: dimensions, measurement, and validation. Acad. Management, [72].

75. Sturner, W.F. (1972): Environmental code: Creating a sense of place on the college campus. J. Higher Education, [33], 97-103.

76. Taber, T.D. and Seashore, S.E. (1975): Job satisfaction and their correlations. American Behavior and Scientists. [83], 346-350.

77. Thomas KW, Velthouse BA. (1990): Cognitive elements of empowerment an interpretive model of Intrinsic task motivation. Acad. Manage. Rev, [71].

78. Tiemey' W.G. (1988): Organizational culture in higher education, defining the essentials. Journal of Higher Education, [31], 19.

79. Trice, H.M., \& Beyer, J.M. (1993): The cultures of work organizations. Englewood Cliffs, NJ: Prentice-Hall ISBN 10: 0131914383, [2].

80. Trow, M. (1960): The Campus Viewed as a Culture: Research on College Students. Boulder: Western Interstate Commission on Higher Education, 105-123, [6].

81. Uttal, B. (1983): The corporate culture vultures. Fortune, [21], 66-70.

82. Van Maanen, J., \& Barley, S. (1984): Occupational communities: Culture and control in organizations. In B. Staw \& L. Cummings. (Eds). "Research in organizational behavior. Greenwich, CT: JAI, [46], 287-365.

83. Van Vianen, A.E.M. (2002): Person-organization fit: The match between newcomers' and recruiters' preferences for organizational cultures. Personnel Psychology, [58], 113- 150.

84. Wang, G., \& Lee, P. D. (2009): Psychological empowerment and job satisfaction: an analysis of interactive effects. Group Organization Management, [78], 271- 296.

85. Whetten DA, Cameron KS. (1998): Developing Management skills. New York: Addison - Wesley, [68].

86. Yang, S. \& Choi, S. O. (2009): Employee empowerment and team performance: Autonomy, responsibility, information, and creativity. Team Performance Management, [75], 289 - 301.

87. Zsóka, A.N. (2007): The role of organizational culture in the environmental awareness of companies. Journal for East European Management Studies, [38], 119-130. 